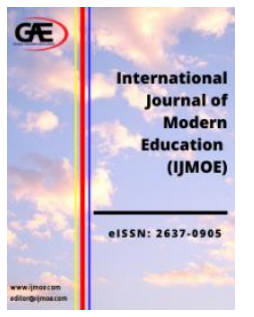

\author{
INTERNATIONAL JOURNAL OF \\ MODERN EDUCATION \\ (IJMOE) \\ www.ijmoe.com
}

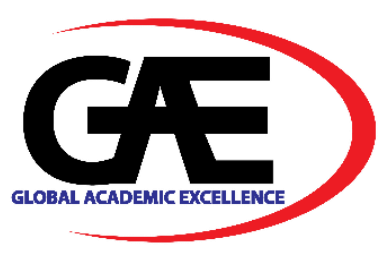

\title{
LEARNING ACTUARIAL MATHEMATICS THROUGH UITM FUTURE MOOC
}

\author{
Mohd Zaki Awang Chek ${ }^{1 *}$, Isma Liana Ismail ${ }^{2}$, Nur Faezah Jamal ${ }^{3}$ \\ 1 Center for Actuarial Studies, Universiti Teknologi MARA, Perak Branch, Malaysia \\ Email: mohdz220@uitm.edu.my \\ 2 Center for Statistics and Decision Science, Universiti Teknologi MARA, Perak Branch, Malaysia \\ Email: ismal246@uitm.edu.my \\ 3 Center for Statistics and Decision Science, Universiti Teknologi MARA, Perak Branch, Malaysia \\ Email: nurfa210@uitm.edu.my \\ * Corresponding Author
}

\section{Article Info:}

\section{Article history:}

Received date:21.07.2020

Revised date: 28.07 .2020

Accepted date: 16.08 .2020

Published date: 10.09.2020

\section{To cite this document:}

Awang Chek, M. Z., Ismail, I. L., \& Jamal, N. F. (2020). Learning Actuarila Mathematics Through UiTM Future MOOC. International Journal of Modern Education, 2(6), 08-13.

DOI: $10.35631 / \mathrm{IJMOE} .26002$

\begin{abstract}
:
The Massive Open Online Courses (MOOCs) is a new online learning platform that provides training beyond the classroom based on casual and social learning. Current learning methods that use PowerPoint slides usually bore students who would easily lose focus on their learning. MOOCs provide a new era of learning style with various learning methods. Using attractive notes with the aid of video, animation, and a variety of activities to promote a better learning environment adaptively. It is accessible anytime, anywhere, and gives flexibility to students in managing their learning routine. Therefore, UiTM Perak (Tapah Campus) has taken an initiative to implement MOOCs in one of the diploma subjects which is "Introduction to Actuarial Mathematics" (ASC305). Actuarial Mathematics is a subject taught under the actuarial science program in preparation for the professional actuarial examination under the Society of Actuaries (SOA), as well as getting students to understand the actuarial aspects of the current life insurance system. On top of that, this MOOC has encouraged worldwide participants where one will have experience in practicing their fundamental knowledge on each topic. The real-time communication between the instructor and participants for knowledge sharing, brainstorming, and exchanging opinions create a positive ambiance of "classroom-beyond-borders". Using MOOCs for the course opens great opportunities for instructors to be creatively and innovatively involved in preparing attractive content, learning activities, and hands-on assessments that suit all learning styles (auditory, visual, reading and writing, and kinesthetics). Thus, this paper illustrates and describes the development of Introduction to Actuarial Mathematics using MOOCs (https://ufuture.uitm.edu.my/courses/summary/ASC305).
\end{abstract}




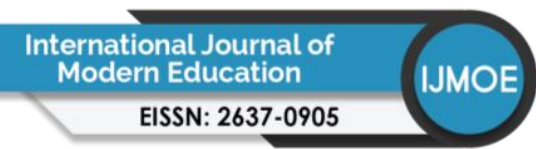

Volume 2 Issue 6 (September 2020) PP. 08-13

DOI: 10.35631/IJMOE.26002

Keywords:

Actuarial Mathematics, Blended Learning, MOOC, UFuture

\section{Introduction}

The Massive Online Open Courses (MOOCs) are becoming popular in universities as well as in learning mathematics as a learning tool. Mathematics plays an important role in the insurance industry and there is a growing demand for graduates with knowledge and understanding of both financial matters and the relevant mathematics (Haslifah Mohamad Hasim, 2015). This course provides thorough training in both aspects with a range of modules in economics, finance and mathematics, including specialist modules that deal directly with applications of mathematics in life insurance (Kellison, 2009). Therefore, this paper illustrates and describes the use of a Massive Open Online Course (MOOC) Universiti Teknologi MARA (UiTM) to deliver actuarial mathematics for UiTM's Actuarial Science students in Malaysia. It also provides a platform to deploy innovative techniques, enhancing positive thinking through blended learning (Brahimi \& Sarirete, 2015).

\section{Current Issues in Teaching and Learning}

Blended learning is a combination of e-learning, face-to-face and autonomous studies. It has been increasingly popular in recent years, in response to online learning progress. Among them: Online discussions, messages and feedback from lecturers and peers. The course is accessible 24/7 - any time from any location (Spyropoulou, Demopoulou, Pierrakeas, Koutsonikos, \& Kameas, 2015). While student assessment and automatic grading offered by many learning systems can also help students to improve their existing knowledge. This caters to the style? and learning style? of each student, creating a more comfortable environment for both parties. If students have problems with a particular topic, they can reach web resources complementing or get quick help from their instructors (Leito, Helm, \& Jalukse, 2015). Mohd Nor Hajar Hasrol, Mohamad, Rahayu, Nor Azilah, \& Azlan, (2013) state that the current issues in teaching and learning are:

i. Lack of space and time

ii. All communications are not archived for future reference

iii. Communication in groups

iv. Motivate students for self-learning

v. Low and medium levels of student interaction and accountability.

vi. Difficult to share ideas and responsibilities

\section{Advantages of Using MOOC}

These are advantages of using MOOC $(\mathrm{Ng}, 2014)$ :

i. Decreases dependency on class instructors.

ii. Provides wider opportunities for students to engage in learning.

iii. Saves cost.

iv. Reduces the number of F2F class hours.

v. Enhances students' learning and retentive ability.

vi. Gives designers and learners more than one medium or delivery channel to meet learning objectives.

vii. Promotes a continuous learning approach that is more effective at creating change and deep learning. 


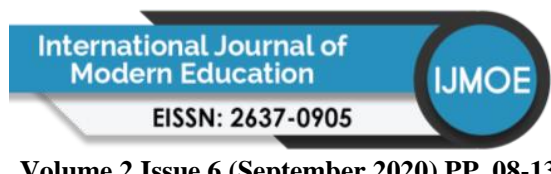

Volume 2 Issue 6 (September 2020) PP. 08-13

DOI: $10.35631 /$ IJMOE.26002

viii. Provides more opportunities for social learning, collaboration, increased participation, and informal strategies.

ix. Uses both synchronous and asynchronous approaches that can provide more opportunities for learners to cultivate skills and apply them.

x. Has potential for faster development and reduced costs depending on the approaches that are selected.

xi. Employs technology-enabled delivery that can reach a geographically dispersed audience.

\section{Massive Open Online Courses UiTM}

UiTM Future (UFuture) is a UiTM learning management platform. It is an introduction to fit the new approach to learning that dominates current life styles, especially that of the younger generation (Sardi et al., 2016; Spyropoulou et al., 2015). The four main features of MOOC are course information, learning materials, learning activities and course assessments. These features are consistent with the need for Blended Learning Mode which is listed as one of the main elements in the National e-learning Agenda. The implementation of MOOC is also guided by the Dasar e-Pembelajaran Negara (DEPAN) formulated by the Ministry of Education, Malaysia (Aziz, 2018; Spyropoulou et al., 2015).

MOOC is connected with UiTM's Integrated Academic System. Student and lecturer accessibility to MOOC is concurrent with the course registration module and lecturer's teaching assignment. The use of MOOC starts at the beginning of a semester. Students and lecturers may access MOOC's features based on their list of course registration. At the same time, lecturers can upload and update learning materials and information about the course. Throughout the semester, most of the learning activities that involve students and lecturers are available in MOOC. MOOC is accessible through any browser and mobile application via Open Learning mobile application (Mohd Nor Hajar Hasrol, Mohamad, Rahayu, Nor Azilah, \& Azlan, 2013; Shuang ${ }^{\mathrm{a}}$, Azeezeen, Tengku, Thambyraja ${ }^{\mathrm{a}}$, \& Ibrahim ${ }^{\mathrm{b}}$, 2012).

\section{Introduction to Actuarial Mathematics MOOC}

This course introduces students to a real actuarial working environment. The syllabus for this course provides a basic understanding of actuarial mathematics, including understanding basic knowledge and applying that knowledge purposely for life insurance premiums calculations. Its goal is to provide students with first-hand exposure in modelling and actuarial analysis as basic knowledge before proceeding to the Advanced Actuarial Mathematics course in the later semesters of the Actuarial Science Programme (Ng, 2014; Ridzuan, Chek, Ghafar, \& Ahmad, 2018). Therefore, at the end of the course, students should be able to:

i. Explain the basic theory of actuarial mathematics.

ii. Identify, formulate, and solve basic actuarial mathematics.

iii. Apply basic knowledge of actuarial mathematics in the field of life insurance business. The main features of MOOC for this course are course information, learning materials, learning and assessment activities courses. These features are consistent with the requirements of the Combined Learning Mode listed as one of the key elements in the National e-learning Agenda (Aldon et al., 2017). 


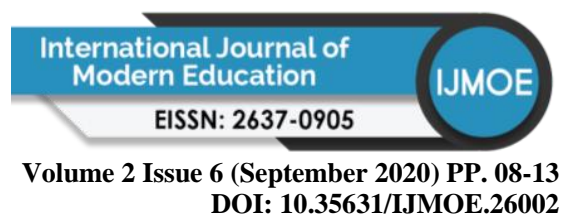

\section{Involvement of Students}

The implementation of MOOC enables students to achieve the objectives of the Higher Education Strategic Plan from three perspectives: cognitive, psychomotor, and affective. The plan strives to produce knowledgeable graduates who are competent and able to put knowledge into practice (Jabatan Pendidikan Tinggi, 2017; Jisoo, Ahreum, \& Junseok, 2018; Sardi et al., 2016). Online learning courses offer flexibility since they allow students to plan their study based on their time preferences. The virtual classroom can also save time as they can study at any time. They do not have to go to the library since course materials are always available online. Thus, students can study at their own pace and composure (Shah, 2016; Wang \& Xu, 2016).

\section{Evaluation of UiTM Future (UFuture) MOOC}

The use of MOOC at the beginning of the semester enables lecturers to monitor students' performance throughout the semester according to the planned learning activities. As it is accessible almost anywhere and anytime and due to the automatic grading system, it will assist students in improving their understanding of the subject matter, while making it easy for lecturers to assess their students. If students face difficulty while learning through MOOC, they can access any web sources to get immediate additional information to help them understand the subject contents.

To measure the effectiveness of using Actuarial Mathematics through UFuture MOOC as a compulsory learning platform for all students, the examination results from two consecutive semesters in which this course is offered are compared. The passing rate for the two semesters (Sept 2018 - April 2019 and Sept 2019 - April 2020) are compared by mapping to the course learning outcomes (CLO). It shows that passing marks for both semesters more than $90 \%$ as compared previously on average $85 \%$.

\section{Discussion}

As blended learning combines e-learning with traditional classroom teaching, it is easier for students to have an online discussion and get feedback from lecturers as they usually like to spend their time using the internet (Brahimi \& Sarirete, 2015; Chek, Ismail, \& Jamal, 2019; Jacobsen, 2019). The study conducted by Brahimi, and Sarirete, (2015) also stated that students tend to use social networking sites to connect with classmates and stay current with class news regarding exams and homework. Additionally, most of them are active in learning outside the classroom, especially for Actuarial Mathematics subject. Besides, Kumar, and Al-Samarraie, (2018) also found that a blended learning environment can support students' learning, particularly mathematical thinking.

\section{Conclusion}

Actuarial Mathematics is a subject taught under the actuarial science program in preparation for the professional actuarial examination under the SOA and is one of the requirements for CM1 exemption under the Institute and Faculty of Actuaries (IFoA) in UiTM (Aziz, 2018; Koper \& Tattersall, 2005; Ng, 2014; Ridzuan et al., 2018). As students face difficulties due to limited face-to-face classroom learning and time constraint on teaching the subject contents for the lecturers, the implementation of UFuture MOOC helps in making the learning process easily accessible with unlimited course resources. 


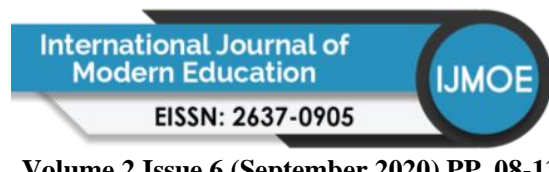

Volume 2 Issue 6 (September 2020) PP. 08-13

DOI: 10.35631/IJMOE.26002

Additionally, learning Actuarial Mathematics through UFuture MOOC is a suitable platform for students and it is compulsory to them to join the course. The features available in this MOOC also make it possible for lecturers to deliver the subject matter more interactively and interestingly as compared to traditional classroom teaching.

\section{References}

Aldon, G., Arzarello, F., Panero, M., Robutti, O., Taranto, E., \& Trgalová, J. (2017). Mooc for Mathematics Teacher Training: Design Principles and Assessment, 1-8.

Aziz, A. (2018). Evaluating the Design Standard of UiTM Massive Open Online Courses. International Journal of Education and Literacy Studies, 6(4), 138. https://doi.org/10.7575/aiac.ijels.v.6n.4p.138

Brahimi, T., \& Sarirete, A. (2015). Computers in Human Behavior Learning outside the classroom through MOOCs. Computers in Human Behavior, 51, 604-609. https://doi.org/10.1016/j.chb.2015.03.013

Chek, M. Z. A., Ismail, I. L., \& Jamal, N. F. (2019). Personal Financial Planning through Massive Open Online Course. International Journal of Academic Research in Business and Social Sciences, 9(5), 618-622. https://doi.org/10.6007/IJARBSS/v9-i5/6004

Haslifah Mohamad Hasim. (2015). A conceptual framework for the establishment of a government actuary's department in Malaysia. Journal of Business and Social Development, 3(2), 17-33.

Jabatan Pendidikan Tinggi. (2017). Garis Panduan Pambangunan dan Penyampaian MOOC Malaysia. (Jabatan Pendidikan Tinggi, Ed.) (1st ed.). Putrajaya: Jabatan Pendidikan Tinggi.

Jacobsen, D. Y. (2019). Dropping Out or Dropping In? A Connectivist Approach to Understanding Participants' Strategies in an e-Learning MOOC Pilot. Tech Know Learn, 24, 1-21. https://doi.org/10.1007/s10758-017-9298-z

Jisoo, L., Ahreum, H., \& Junseok, H. (2018). A Review of Massive Open Online Courses: MOOC's Approach to Bridge the Digital Divide. In 22nd Biennial Conference of the International Telecommunications Society(ITS) : "Beyond the Boundaries: Challenges for Business, Policy and Society”. (pp. 1-20). Seoul, Republic of Korea.

Jono, M., Mohamad, I., Rahayu, H., Nor Azilah, M. A., \& Azlan, A. A. (2013). e-Materials Application Presentation Using Gagne Learning Theory for "Introduction to $\mathrm{C}++$ Computer Programming," 122-127.

Kellison, S. G. (2009). The Theory of Interest (3rd ed.). Singapore: Mc Graw Hill.

Koper, R., \& Tattersall, C. (2005). Preface to Learning Design: A Handbook on Modelling and Delivering Networked Education and Training. Journal of Interactive Media in Education, 18, 1-7.

Kumar, J. A., \& Al-Samarraie, H. (2018). MOOCs in the Malaysian higher education institutions: The instructors' perspectives. Reference Librarian, 59(3), 163-177. https://doi.org/10.1080/02763877.2018.1458688

Leito, I., Helm, I., \& Jalukse, L. (2015). Using MOOCs for teaching analytical chemistry: experience at University of Tartu. Analytical and Bioanalytical Chemistry, 407(5), 1277-1281. https://doi.org/10.1007/s00216-014-8399-y

Mohd Nor Hajar Hasrol, J., Mohamad, I., Rahayu, H., Nor Azilah, M. A., \& Azlan, A. A. (2013). e-Materials Application Presentation Using Gagne Learning Theory for "Introduction to $\mathrm{C}++$ Computer Programming." In International Conference on Education and Modern Educational Technologies (pp. 122-127). Kuala Lumpur. 


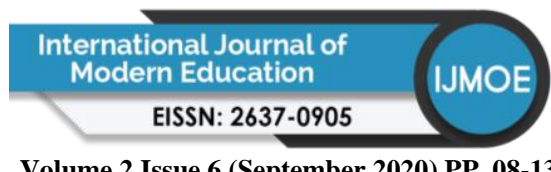

Volume 2 Issue 6 (September 2020) PP. 08-13 DOI: 10.35631/IJMOE.26002

Ng, R. (2014). The Teaching and Learning of Mathematics Via Online : Sharing a Lifelong Learning Experience At Open University Malaysia. In Seminar Kebangsaan Pembelajarn Sepanjang Hayat (pp. 263-269).

Ridzuan, A. N. A. A., Chek, M. Z. A., Ghafar, N. M. A., \& Ahmad, A. B. (2018). Developing an Introduction to Actuarial Science MOOC. International Journal of Academic Research in Business and Social Sciences. https://doi.org/10.6007/IJARBSS/v8i1/3833

Sardi, J., Hussin, A. A., Luaran, J. E., Noor, H. M., Jono, N. H. H., Noh, N. M., ... Ismail, S. R. (2016). Garis Panduan Pembangunan e-Kandungan Kursus. (J. Sardi \& A. A. Hussin, Eds.), Penerbit UiTM Press (1st ed., Vol. 53). Shah Alam: UiTM Press. Retrieved from http://dx.doi.org/10.1016/j.tws.2012.02.007

Shah, D. (2016). Monetization over Massiveness: A Review of MOOC Stats and Trends in 2016 - Class Central. Retrieved from https://www.class-central.com/report/moocs-statsand-trends-2016/

Shuang $^{\mathrm{a}}$, G. C., Azeezeen, T., Tengku, B., Thambyraja ${ }^{\mathrm{a}}$, M. T., \& Ibrahim $^{\mathrm{b}}$, Z. B. (2012). An Explotary Of Multimedia E-Learning Materials In Teaching And Learning Of Mandarin Chinese Language, (InCULT).

Spyropoulou, N., Demopoulou, G., Pierrakeas, C., Koutsonikos, I., \& Kameas, A. (2015). Developing a Computer Programming MOOC. Procedia Computer Science, 65(Iccmit), 182-191. https://doi.org/10.1016/j.procs.2015.09.107

Wang, F., \& Xu, X. (2016). Discussion on the Teaching Method of Probability Theory and Mathematical Statistics, 177(Erms), 208-212. https://doi.org/10.2991/icpel-16.2016.26 